\title{
An Analysis of Social Deixis in the Madness of King George Movie
}

\author{
Zovi Dwi Putra \\ English Education Study Program, Department of Language and Art \\ University of Bengkulu \\ zovidwiputra390@gmail.com \\ Dedi Sofyan \\ English Education Study Program, Department of Language and Art University of \\ Bengkulu \\ sofyandedi@rocketmail.com \\ Barnabas Sembiring \\ English Education Study Program, Department of Language and Art \\ University of Bengkulu \\ Barnabasdepari@gmail.com \\ Corresponding author: zovidwiputra390@gmail.com
}

\begin{abstract}
This research aimed at finding out the kinds of social deixis and to explain the social stratification factors in each kind of social deixis in The Madness of King George movie. The type of this research was descriptived qualitative research. Instrument of research that used in this research is the documentation (library research). The matrix table used to collect the data about social deixis in the Madness of King George Movie. According to the matrix table, there are 965 kinds of Relational Social Deixis and 504 kinds of Absolute social deixis used in this movie. The dominant type of Relational Social Deixis is first personal pronoun which refers to the speaker itself. It was used 279 times from total of social deixis used in this movie. In Absolute Social Deixis category, the dominant type was "Sir" which was used 144 times. It was also explained that Relational Social Deixis category is dominant with the frequency of usage around 965 times more than Absolute Social Deixis with the frequency of usage around 504 times from total of social deixis used in this movie. Third, there were three factors of social stratification used in all utterances contained social deixis in this movie. It was found that the dominant social deixis, whether Relational or Absolute Social Deixis, refered to the male characters than the female characters. Because in the 19th century, the man held more power to lead the society and dominant in public relations, especially in Kingdom territory.
\end{abstract}

Keywords: Social Deixis, Social Stratification, Movie

\section{A. Introduction}

Pragmatics is one of the linguistics parts which involved deixis, maxim, reference, politeness and other parts (Yule, 1996; Syafryadin, et al., 2020). Deixis is an important part of language study and it is very useful for learner of languages. It has some relevances in analyzing the conversation and pragmatics. It is often described as "verbal pointing", that is to say pointed by means of language. Deixis is also occurred in the conversation of dialogue because dialogue is one of speaking activities and it has rethorical structure (Diani, et al, 2019; Nurman, et al., 2019; Syafryadin, 2020; Syafryadin, et al. 2020; 
Noermanzah, et al. 2020; Noermanzah, et al., 2020). Levinson (1983) stated that deixis concerns the way in which languages encode or grammatical features of the context of utterance or speech event, and thus also concern with the ways in which the interpretation of utterances depends on the analysis of that context of utterance. Based on the statement above, we can say that deixis is a part of pragmatic which is focused on way of language encodes and grammatical features of context in utterances, then it is also focused on the way of interpretation in utterances depends on the context. Beside that, Mclntyrel (2004) stated that deixis is a term which used for a phenomenon in linguistics that demonstrates the obvious relationship between language and context.

Deixis is divided into five types, there are personal deixis, time deixis, place deixis, social deixis and discourse deixis (Levinson: 1983). The first type is personal deixis. Personal deixis is a word that refers to someone in certain context of the utterance. In line with Levinson (1983), personal deixis is deictic that refers to the participant role of reference, such as the speaker, the addressee, and the referent which are neither speaker nor addressee. Second is time deixis, time deixis is absolutely every deictic expression are inextricably linked from the other deixis, they always linked. Third is place deixis, the place relation between the speaker and thing that speaker mean. In accordance with Levinson (1983), place deixis concern the encoding of spatial locations relative to the location of the participants in the speech. Place or location can be deixis if that place or location can be seen from the location of the people who are doing communication in speech event. Fourth is social deixis. It concerns the encoding of social distinctions that are relative to participant-roles, particularly aspects of the social relationship holding between speaker and addressees or speaker and some referent (Levinson, 1983). The last is discourse deixis. Discourse deixis has to do with the encoding of reference to portions of the unfolding discourse in which the utterance (which includes the text referring expression) is located (Levinson, 1983).

This research focused on social deixis. Levinson (1983) stated that social deixis concerns with the aspects of sentences which reflect or establish or determined by certain realities of participants or the social situation in which the speech event occurs. It means that social deixis is a category that indicates the social status of participants or referents in a speech event. In other words, we can say that social deixis is a kind of expressions used to categorize some people based on their social situations. 
In line with Levinson (1979, referring to Lyons 1968), these categories of deixis can be extended by adding one more category. The one of social deixis, which Fillmore (1975) defined as the study of that aspect of sentences which reflect or establish or are determined by certain realities of the social situation in which the speech act occurs. Theories used in this research is the deixis expressions from Stephen C. Levinson (1983) and blending theories of social variation by Janet Holmes (1992) with social stratification by David Crystal (2010). In deixis expressions theory, Levinson explain that there are five types of deixis expression, they are: person deixis, place deixis, time deixis, discourse deixis and social deixis. In the social variation theory, Holmes explain about classes of people that use RP (Received Pronunciation) as a standard accent. The last is theory of social stratification, Crystal divided into three factors, they are: family, rank and occupation.

Deixis is usually used to analyze many objects. One of them is films/movies. They are cultural artifacts created by specific cultures, which reflect those cultures, and, in turn, affect them. Film is considered to be an important art form, a source of popular entertainment and a powerful method for educating or indoctrinating citizens. The visual element of cinema gives motion pictures a universal power of communication. Some films have become popular worldwide attractions by using dubbing or subtitles that translate the dialogue. (http://www.filmsite.org/filmgenres.html).

In this study, the researchers tried to analyze the use of social deixis in a movie, particularly in The Madness Of King George movie. The reason why the researchers interests to analyze movie because the movie is the closest form or version of a real-life, that has the similar form of dialogue or situation in reality life. It is also the good media to learn English Pragmatic, especially deixis. Another reason why the researchers interest to analyze this movie, because this movie tells us about the social status in British on 1788 especially in British Kingdom territory. For more specific, the researchers used this movie to analyze social deixis because it has many dialogues/utterances that contain the types of social deixis in English. That's why the researchers chose social deixis as the research focus and The Madness Of King George movie script as the research object.

\section{B. Research Methodology}


The researcherss used a descriptive qualitative quantitative method. The descriptive study is appropriate to expose facts related to the problem which is going to be discussed. In line with Gay (1991), descriptive method is considered appropriate to describe the present condition of research subject. Arikunto (2002) also states that the descriptive research as a research that explains or describe the present condition. In accordance with the opinions, the researchers designs this research as descriptive research.

Moreover, the researchers chooses the population and sample from the movie dialogue, that is some dialogue or all dialogue of the character in The Madness of King George movie. As Thomas Crowl states that "Populations are groups consisting of all people to whom a researchers wishes to apply the findings of a study". Crowl also states that "sample are subsets of people used to represent populations." (Crowl, 1996:8).

The instruments of research that used in this research is the documentation (library research). It means the researchers use the documentation way (watching movie) to carry out the research and find the data. The researchers provides the matrix table for collecting and analyzing data. Matrix table is the data card used by researchers to put the data, to classify, to identify and to analyze the data.

The researchers collect the data from The Madness of King George movie script, and it is the document of The Madness Of King George movie that the researchers get from internet. There are several steps that the researchers use to collect the data, as follows: First step the researchers watches The Madness of King George movie, The researchers observes the utterances in the movie`s dialogue, The researchers finds the movie script of The Madness of King George on http://www.script-orama.com/movie_scripts $/ \mathrm{m} / \mathrm{madness-of-king-george-script.html}$, The researchers compares the dialogue in the movie to the movie script, The researchers identify the utterances in the whole of movie`s dialogue that contains social deixis and The researchers put the data into the matrix table. The matrix table help the researchers to classify, to identify and to analyze the data.

Moreover, As Rackham (1984:366) said that in observing a work of art. First, look at the whole, then look at more closely at the details, then interpret what you find, and finally from a judgment. Based on statement above, the procedure of data analysis are: Finding the types of the social deixis used in The Madness of King George movie dialogue, Classifying which one of social deixis is included in absolute social deixis, 
Describing the reference meaning of social deixis that use in The Madness of King George movie and Drawing the conclusion and suggestion based on the data analysis.

\section{Results and Discussion}

\section{Results}

Table 1. The Percentage of Social Deixis Use in The Madness of King George Movie

\begin{tabular}{|c|c|c|c|c|}
\hline No. & $\begin{array}{l}\text { Type of } \\
\text { Social } \\
\text { Deixis }\end{array}$ & Social Deixis & Frequency & Percentage \\
\hline \multirow[t]{9}{*}{1.} & \multirow{9}{*}{$\begin{array}{l}\text { Relational } \\
\text { Social } \\
\text { Deixis }\end{array}$} & $\mathrm{Papa} / \mathrm{Pa} /$ Father & 40 & $2.72 \%$ \\
\hline & & Mama/Mother & 4 & $0.27 \%$ \\
\hline & & The son & 18 & $1.22 \%$ \\
\hline & & I/my/myself/mine & 279 & $18.99 \%$ \\
\hline & & You/your/yourself/yours & 266 & $18.10 \%$ \\
\hline & & He/his/himself/him & 179 & $12.18 \%$ \\
\hline & & She/her/her & 20 & $1.36 \%$ \\
\hline & & We/our/ourselves/us & 91 & $6.19 \%$ \\
\hline & & They/their/themselves/them & 68 & $4.62 \%$ \\
\hline \multicolumn{3}{|c|}{ Total of Relational Social Deixis } & 965 & $65.70 \%$ \\
\hline \multirow[t]{15}{*}{2.} & \multirow{15}{*}{$\begin{array}{l}\text { Absolute } \\
\text { Social } \\
\text { Deixis }\end{array}$} & Majesty & 87 & $5.92 \%$ \\
\hline & & Royal Highness & 8 & $0.54 \%$ \\
\hline & & King & 77 & $5.24 \%$ \\
\hline & & Queen & 3 & $0.20 \%$ \\
\hline & & Lord & 15 & $1.02 \%$ \\
\hline & & Mr. & 46 & $3.13 \%$ \\
\hline & & Mrs. & 12 & $0.81 \%$ \\
\hline & & Ma'am & 1 & $0.06 \%$ \\
\hline & & Sir & 144 & $9.80 \%$ \\
\hline & & Sire & 2 & $0.13 \%$ \\
\hline & & Madam & 12 & $0.81 \%$ \\
\hline & & Lady & 6 & $0.40 \%$ \\
\hline & & Captain & 9 & $0.61 \%$ \\
\hline & & The King & 67 & $4.56 \%$ \\
\hline & & The Prince & 15 & $1.02 \%$ \\
\hline \multicolumn{3}{|c|}{ Total of Absolute Social Deixis } & 504 & $34.30 \%$ \\
\hline \multicolumn{3}{|c|}{ Total of Social Deixis } & 1469 & $100 \%$ \\
\hline
\end{tabular}

Based on the matrix table above, we can see that the dominant types of social deixis used in this movie is Relational Social Deixis with 965 times of deixis use. Relational Social Deixis used to explain the relation between the speaker and addressee. It explained who is the speaker and what is the relation between the speaker and their addressee. In line 
with Levinson's theory, pronouns are included in Relational Social Deixis so that it is also categorized in this category.

Relational Social Deixis "Papa/Pa/Father" refers to the character in this movie who have the parent relationship with the speaker. This social deixis used for 40 times $(2.72 \%)$. It refers to the King George as main character in this movie whether as the father of his children. It used by his children to call him. "Mama/Mother" also used by the children to call their mother. In this case, the character of mother is Queen Charlotte. It used only 4 times $(0.27 \%)$ during this movie. This social deixis is the least use in Relational Social deixis because the call "Mother" is only used when the king's children call their mother in family context, not in kingdom government. It can be seen from appendix 2 that the social deixis Mother/Mama is only used by their children. For "The son", it used for 18 times (1.22\%) to explain the addressee of this utterances refers to the son of King George and Queen Charlotte.

As the researchers explained before, pronoun included subject pronoun, object pronoun, possessive adjective or possessive pronoun also included in this category. It will explain the relation between the speaker and addressee in an utterance. The first, pronoun refers to the first speaker (I, my, myself, mine) with the frequency of use around 279 times (18.99\%). This pronoun is not only referred to someone says, but also all of the speaker who have the position as main speaker or first speaker.

Second, the pronoun of second speaker (You, your, yourself, yours) with the frequency of use around 266 times (18.10\%). It refers to the addressee of utterances, include whoever talked with the first speaker. It can be seen that the first and second personal pronoun is the dominant types in Relational social deixis. It is because that in this movie, almost all characters use this type in speaking with other people that they know. In other words, they use this type to speak with closest-relation people with the speaker like friends, family, etc.

Third, the pronouns of single third speaker are divided by single male third speaker (He, his, himself, him) and single female third speaker (She, her, herself). Pronoun of single male third speaker definitely dominant than single female third speaker. Pronoun of single male third speaker used by the character in their utterances around 179 times $(12.18 \%)$. This is inversely proportional to the pronoun of single female third speaker which used around 20 times $(1.36 \%)$. 
Fourth, the pronoun of plural person included (we, our, ourselves, us) and (they, their, themselves, them). The first category of plural person pronoun is (we, our, ourselves, us) used by the character around 91 times $(6.19 \%)$. While the second category of plural person pronoun is (they, their, themselves, them) used for 68 times (4.62\%). Both of this category used by the speaker to explain the character who included or not in the direct conversation. In conclusion, there are 965 times $(65.70 \%)$ of Relational Social Deixis used by the characters in The Madness of King George Movie.

Table 2. Example of Relational Social Deixis Use in The Madness of King George Movie

\begin{tabular}{|c|l|l|}
\hline No. & $\begin{array}{c}\text { Kinds of Relational } \\
\text { Social Deixis }\end{array}$ & \multicolumn{1}{|c|}{ Example of Utterances } \\
\hline 1. & Papa & Amelia: Papa! Ahem. Papa, Papa! Lift me up! \\
\hline 2. & You & $\begin{array}{l}\text { Queen Charlotte: George! Smile, you lazy } \\
\text { hound. It's what you're paid for. Smile and } \\
\text { wave. Come on. Smile and wave. }\end{array}$ \\
\hline
\end{tabular}

In the first utterance, the relational social deixis used is Papa. It refers to "Father" or "Dad". In this utterance, it happened when the youngest daughter of King George cried because of her toys are broken by the Kingdom Equerry. She cried and then went to her father to say something. She surprised when she saw her father are wearing a crown. So, she smile and called her father and want to lifted her up. This utterance explained how is the relationship spoken between daughter and her father. It can be understood from the utterance clearly and easily. The situation or context about the daughter who cried and called her dad to lift her up can be imagined when the reader read or listen the utterance.

The second utterances used relational social deixis "You". In line with Levinson's (1983) statement that in English, relational social deixis may be a lexical item (e.g. my husband, teacher, cousin, etc), pronouns (you, her, etc). In the second utterance in table 4.2, The King George's wife, Queen Charlotte, said to her first son, George, to smile and wave his hand in order to respect his father in front of their people.

In this utterance, "You" refers to George, the first son of the Kingdom. When his mother said it to him, it seems as usual. Absolutely, the reader can read the situation and the relation between George and Queen Charlotte, that is a relationship between son and 
his mother. So, it is not a formal way to call the Kingdom Prince, because it is said by the Queen Charlotte, his mother itself.

The next part is about Absolute Social Deixis. It is usually expressed in certain forms of address which will include no comparison of the ranking of the speaker and addressee. In other words, it explained the speaker or addressee by using special way for authorized recipient. Because in this movie have a background story of England Kingdom, this part absolutely dominant with the special nickname of kingdom.

First, the Absolute Social Deixis used by the speaker in this movie is Majesty. It usually refers to the special people who have high social status in a society. In this movie, absolutely it refers to the King George as the main Character and the person who have highest social status (King) of England Kingdom. It used by some characters' utterances when he or she have a direct conversation with King George or indirect conversation about the King itself. This Absolute Social Deixis used for 87 times (5.92\%).

Second is Royal Highness. In this movie, it was usually used by the society when they were talking with the family member of England Kingdom like King, Queen, Prince or Princess. It used to express the respect for The Kingdom's family member. In this category, the researchers found around 8 times $(0.54 \%)$ of use.

Third Absolute Social Deixis is King. In this movie, the word "King" absolutely addressed to the only one person, King George. It refers to King George as main character in this movie. It takes the second position of most dominant Absolute social deixis used in this movie. It caused that King George is the main character in this movie. While "Queen" refers to the wife of King George, Queen Charlotte. Those two persons have important role in The Madness of King George movie. The Absolute Social Deixis "King" used for 77 times (5.24\%) while the word "Queen” used only 3 times (0.20\%).

Next, the Absolute Social Deixis "Lord" also used in this movie. Lord means an appellation for a person or deity who has authority, control, or power over others acting like a master, a chief, or a ruler. The appellation can also denote certain persons who hold a title of the peerage in the United Kingdom, or are entitled to courtesy titles. The collective "Lords" can refer to a group or body of peers. In this movie, Lord refers to some characters like Lord Chancellor and Lord Thurlow. Based on the table of Social Deixis used in this movie, "Lord" used 15 times (1.02\%) to explain the character of Lord Chancellor and Lord Thurlow. 
Then, "Mr" and "Mrs" also used in this movie to explain the male and female character. Mister, usually written in its abbreviated form "Mr" (UK) or Mr. (US), is a commonly used English honorific for men under the rank of knighthood. In past centuries, "Mr" was used with a first name to distinguish among family members who might otherwise be confused in conversation. While "Mrs" used for same situation but it refers to women. In this movie, Absolute Social Deixis "Mr" used for 46 times (3.13\%) and "Mrs" for 12 times $(0.81 \%)$.

In addition, "Ma'am" addressed to the old woman who have a child or adult woman. In this movie, it used for only 1 time (0.06\%). While "Sir" and "Sire" addressed for adult man or respective man. "Sir" is a formal English honorific address for men, derived from "Sire" in the High Middle Ages. Traditionally, as governed by law and custom, "Sir" is used for men titled knights i.e. of orders of chivalry, and later also to baronets, and other offices. "Sire" was a respectful form of address for reigning kings in Europe. It was used in Belgium, France, Italy, Germany, Sweden, Spain and the United Kingdom. Historically Sire had a wider usage. During the Middle Ages, "Sire" was generally used to address a superior, a person of importance or in a position of authority or the nobility in general. The Absolute Social Deixis "Sir" used for 144 times (9.80\%) and "Sire" for 2 times (0.13\%). It can be seen from the table 4.1, the dominant type of Absolute social deixis is "Sir". It caused that almost character used "Sir" when they as the speaker told with the man as hearer. As the researchers said before, in this movie, the male character is more than female character. So, the social deixis "Sir" used dominantly in this movie.

Next, "Madam" also used in this movie. "Madam" is a polite term of address to a woman, originally used only to a woman of rank or authority. In this movie, "Madam" refers to Queen Charlotte and Elizabeth. It is similar with "Ma'am" but in different context or situation. It used for 12 times (0.81\%). After "Madam", the Absolute Social Deixis "Lady" is also used for 6 times $(0.40 \%)$ in this movie. The word "Lady" is a term of respect for a woman, the equivalent of gentleman. Once used to describe only women of a high social class or status, now it may refer to any adult woman. In this movie, it refers to Lady Pembroke and Lady Townsend.

Last, the two Absolute Social Deixis are "Captain" and "The Prince". Captain refers to Captain Fitzroy, Captain Cordwell and Captain Greville. While "The Prince" 
refers to Prince Fred, Prince of Wales and Prince George. The Absolute Social Deixis "Captain" used for 9 times (0.61\%) and "The Prince" for 15 times (1.02\%). 


\section{Table 3. Example of Absolute Social Deixis Use in The Madness of King George Movie}

\begin{tabular}{|c|l|l|}
\hline No. & \multicolumn{1}{|c|}{$\begin{array}{c}\text { Kinds of Absolute } \\
\text { Social Deixis }\end{array}$} & \multicolumn{1}{c|}{ Example of Utterances } \\
\hline 1. & Majesty & $\begin{array}{l}\text { Equerry: Petitioners for the king! Petitions } \\
\text { for the king! Present your petition! Open the } \\
\text { gate! Stay with the line. Over there. } \\
\text { Petitioners. The petitioners, Your Majesty. }\end{array}$ \\
\cline { 1 - 1 } 2. & & $\begin{array}{l}\text { Doctor: How long have you been in waiting? } \\
\text { I cannot address His Majesty until he } \\
\text { addresses me. I cannot inquire after His } \\
\text { Majesty's symptoms until he chooses to } \\
\text { inform me of them. }\end{array}$ \\
\hline
\end{tabular}

From the first and second utterances above, Majesty refers to the main character in this movie, King George. In the first utterance, the Equerry showed the respect to the King George to accept the petition from petitioners. So, the equerry used "Your Majesty" to invite the King George to accept the petitions. In this case, "Your Majesty" means the people who have highest social status or position in one community. Based on this movie, King George is the only one highest-position person.

In the second utterances, the situation was when the Doctor said to Captain Greville about the King George's health. The Doctor was not able to inform about the King George's symptoms before the King want him to inform it. In this case, the Doctor use Majesty as third person pronoun position because King George was not involved in this conversation directly.

To answer the second research question, the researchers collected the data about the relation in the utterances in The Madness of King George Movie in the Table 4.4. about Example of Social Deixis and Factors of Social Stratification in The Madness of King George Movie (see on Appendix 1).

The table above is a sample of Relational and Absolute Social Deixis used in the dialogue/utterances of all character in The Madness of King George movie. We can see that the dominant social deixis refers to the King George as the main character in this movie, whether Relational or Absolute Social Deixis. After that, it followed by the Queen, The Prince, the Captain and other characters.

In this movie, there are some factor implied social stratification. As David Crystal (2010) stated there are three factors of social stratification they are: family, rank and occupation. As the data shown in table 4.4, the three of social stratification factors used in 
each utterance contained social deixis. The Family factor used in explaining the relation between the speaker, addressee and hearer etc. who have family relation for each other. The Occupation factor explained about the relation of job or work status between speaker, addressee and hearer etc. Last, the Rank factor explained about the social status of speaker, addressee and hearer etc. seen from the context and topic of utterance.

\section{Discussion}

Based on the previous illustration of findings, there were 1469 item of social deixis used in this movie. Those data were divided into two types of social deixis, namely Relational Social Deixis and Absolute Social Deixis.

Relational Social Deixis was a deictic reference to some social characteristic of referent apart from any relative ranking of referents or deictic reference to a social relationship between the speaker and addressee. While Absolute Social Deixis was a deictic reference usually expressed in certain forms of address which will include no comparison of the ranking of the speaker and addressee.

In this section, the researchers discussed the findings about both of social deixis types found in The Madness of King George movie dialogue. First, it will start from the dominant social deixis found in this movie. The researchers found that the first personal pronoun (I/my/myself/mine) was the dominant Relational Social Deixis used in this movie. It was used 279 times during this movie dialogue. It refered to speaker who produce the utterance. It can be seen that the first personal pronoun is the dominant types in Relational social deixis. As all characters used this type in speaking with other people that they know. Specifically, most of the character spoke by him or herself to other people and they had a role as the first person. In other words, they used this type to speak with closest-relation people with the speaker like friends, family, etc.

From the Absolute Social Deixis, the researchers found that "Sir" was dominant social deixis used in this movie. It used in the dialogue of this movie for 144 times. It was also found by the researchers that the dominant utterances or dialogue refers to the male character than female character. This is because in the 19th century, the man held more power to lead the society and was dominant in public relations. While the least number of Absolute social deixis was "Sire". This type was only used several times. In the data most characters chose "Sir" when they speak with other more than "Sire". As this movie had the background story 
in British Kingdom that used "sir" formally more than "sire" (only used to respect the guest from outside the kingdom itself).

Last, the three of social stratification factors based on Crystal theory also used in each utterance contained social deixis. The Family factor used in explaining the relation between the speaker, addressee and hearer etc. who have family relation for each other. The Occupation factor explained about the relation of job or work status between speaker, addressee and hearer etc. Last, the Rank factor explained about the social status of speaker, addressee and hearer etc. seen from the context and topic of utterance.

In line with explanation of findings above, it can be seen that there are two kinds of social deixis (Relational Social Deixis) and Absolute Social Deixis as explained by theory of (please connect your discussion with the theory from Levinson (1983). It is also found the social stratification used in the Madness of King George Movie as explained by theory of David Crystal.

\section{Conclusion and Suggestion}

\section{Conclusion}

In line with the previous discussions, after all steps the researchers can draw some conclusions. Based on findings, this study found many social deixis used in The Madness of King George movie. It divided by two categories named Relational Social Deixis and Absolute Social Deixis.

Then, the dominant type of Relational Social Deixis is first personal pronoun which refers to the speaker itself (I, my, myself, mine). In Absolute Social Deixis category, the dominant type is "Sir". It is also explained that Relational Social Deixis category is dominant more than Absolute Social Deixis from total of social deixis used in this movie.

Next, there are three factors of social stratification used in all utterances contained social deixis in this movie. They are Family, Occupation and Rank Factor. All of them used to explain the social stratification between the speaker, addressee and hearer etc. It can be seen from the context and topic of utterances.

Last, the researchers found that the dominant social deixis, whether Relational or Absolute Social Deixis, it refers to the male characters (The King, The Prince and so on) than the female characters (Queen, Elizabeth etc). It caused that in the 19th century, the man held more power to lead the society and dominant in public relations, especially in Kingdom territory. 


\section{Suggestion}

After conducting this research, the researchers would like to give some suggestions as follows: For students whose major is English Department, studying English not only to study about four skills, also they must study other language aspect. Moreover, we have to know about other aspects such as structure, contextual meaning and other literary sources. One of them is in pragmatic field, specifically deixis, the English student can understand the meaning, referent and the rule of deixis used in English based on the context. It also can help the students to improve their speaking ability in using deixis, especially social deixis.

For the lectures, the writer wishes that they will be mentors/tutors for other researcherss. It will help them to get the references of deixis research. It also can help them to be the guidance for the further research. Hopefully they will facilitate the English student when they want to try to make the research about pragmatic field.

The writer also hopes that the further research especially dealing with deixis specifically social deixis, it can give a great contribution in terms of English language teaching and learning. The other researcherss had also better in analyzing the contextual meaning of social deixis in written and spoken English text. Hopefully, the further researchers will find another object of the research, and they will find better ideas to improve better findings in English language teaching and learning process.

For people who are learning English or interested in the English, the researchers suggests to try in understanding the use and meaning of deixis, especially social deixis. It can be found in every field like movie subtitle, novel, short story etc. It can be useful to help other people in understanding English everywhere.

\section{References}

Bernard, Bloch and Trager. (1984). Outline of linguistic analysis, in Henry Guntur Taringan, Psikolinguistik. Bandung: Angkasa.

Bodgan, Robert. (1998). Introduction to research. In Halimah, L.N. 2007. Deixis used in "This Odd Word" of "the Jakarta Post". Malang: UIN Malang.pdf.

Brennan, S.E. (2010). Conversation and dialogue. In press, SAGE Publications.pdf.

Bright, William. (1966). Language, social stratification and cognitive orientation. The Hague: Mouton.

Chesire, Jenny. (1982). Linguistic variation and social function. In Suzanne Romaine (ed.) Sociolinguistic Variation in Speech Communities. London: Edward Arnold. 
Cook, G. (1989). Discourse. Oxford: Oxford University Press.

Cruse, D Alan. (2000). Meaning in language: An Introduction to semantics and pragmatics. Oxford: Oxford University Press.

Crystall, David. (2010). The Cambridge encyclopedia of language: Third Edition. United Kingdom: Cambridge University Press.

Cutting, Joan. (2002). Pragmatics and discourse. London: Routledge.

Diani, I., Yunita, W., \& Syafryadin, S. (2019). Interferensi Bahasa Indonesia terhadap Kemampuan Berbicara Bahasa Inggris Mahasiswa Universitas Bengkulu. In Seminar Nasional Pendidikan Bahasa dan Sastra (pp. 164-173).

Effendi. (2002). A Study of deictic expression in Hemmingway's "The Killer" and Austin's Emma through a Discourse Analysis. Unpublished S-1Thesis. Universitas Negeri Surabaya

Faizah, Anely. (2008). Analyzing the deixis found in surah al-dukhan. Malang: State Islam University Malang. Pdf.

Fuanda, Nofiyanti. (2012). The symbols of vampire and werewolf in romance fantasy movie: the Twilight Saga. Yogyakarta: UIN SUKA Yogyakarta.

Hails, Aarti R. (2013). Four types of communication. accessed on 9/15/2014 in http://www.buzzle.com/articles/four-types-of-communication.html.

Hamidah, Lilik Nur. (2007). Deixis used in "This Odd World" of "The Jakarta Post. Malang: State Islam University. Pdf.

Hidayat, Asep Ahmad. (2009). Filsafat bahasa. Bandung, PT Remaja Rosdakarya.

Holmes, Janet. (1992). An Introduction to Sociolinguistics. New York: Addison Wesley Longman Inc.

Horn, Laurence R. and Ward, Gregory. (2006). The Handbook of Pragmatics. The United Stated: Blackwell Publishing Ltd.

Hornby, A.S. (1995). Oxford Advanced Learners Dictionary. London: Oxford University Press.

Jakobson, Roman. (1971). Shifters, verbal categories, and the Russian verb. The Hague: Mouton.

Krasnoukhova, O. (2007). Social deixis and classifiers. Radboud University Nijmegen. Pdf.

Levinson, Stephen C,. (1979). Pragmatics and social deixis. Cambridge: Cambridge University Press. 
Levinson, Stephen C,. (1983). Pragmatics. Cambridge: Cambridge University Press.

Nicholson, William and Hirst, Michael. (2006). Elizabeth: The golden age. Accessed on November 30, 2014.

Noermanzah, N., Syafryadin, S., Castrena, O. W., \& Abid, S. (2020). Rhetoric structure of the master of ceremony and the function of the akikah event in Lubuklinggau City. Journal of English Education and Teaching, 4(2), 232-247.

Noermanzah, et al. (2020). The rhetorical structure of the Lubuklinggau Mayor's speech in building community trust. International Journal of Progressive Sciences and Technologies (IJPSAT), 19(2), 146-154.

Nurman, K., \& Arsyad, S. (2019). Discourse markers in argumentative essay by the English education study program's students of Universitas Bengkulu: A cross-sectional study. Journal of English education and teaching, 3(1), 29-41.

Syafryadin, I. N. R., \& Widiastuti, R. (2013). Improving grade X students' speaking achievement under Round Robin technique. International Journal on Education, 1(1).

Syafryadin, W., \& DEC, A. Noermanzah.(2020). Maxim Variation, Conventional, and Particularized Implicature on Students' Conversation. International Journal of Scientific and Technology Research, 9(2).

Syafryadin, S. (2020). Students' strategies in learning speaking: experience of two indonesian schools. Vision: Journal for Language and Foreign Language Learning, 9(1), 34-47. doi:http://dx.doi.org/10.21580/vjv9i14791 